JURNAL PENDIDIKAN, p-ISSN 2715-095X, e-ISSN 2686-5041

Volume 30, No.3, Nopember 2021 (455-462)

Online: http://journal.univetbantara.ac.id/index.php/jp

\title{
Pengembangan Media Komik Penerapan Sila Pancasila PPKn Kelas 3 di Sekolah Dasar Kabupaten Dharmasraya
}

\author{
Yulia Darniyanti, Nini Efriani, Wiwik Okta Susilawati
}

Universitas Dharmas Indonesia, Jl Lintas Sumatera Km 18, Koto Baru, Dharmasraya, Sumatera Barat, Email: efrianinini@gmail.com

Received: Agustus 27, 2021

Accepted: Oktober 23, 2021

Online Published: Nopember 08, 2021

\begin{abstract}
Abstrak: Penelitian ini dilatar belakangi oleh rendahnya hasil belajar peserta didik, pada mata pelajaran PPKn materi penerapan sila pancasila. Rendahnya hasil belajar peserta didik disebabkan karena peserta didik sulit memahami materi muatan PPKn dan kurangnya variasi media pembelajaran yang digunakan dalam proses pembelajaran pembelajaran dan dibutuhkan media pembelajaran yang inovatif, kreatif. Tujuan penelitian ini adalah untuk menghasilkan media komik penerapan sila pancasila PPKn kelas 3 SD yang valid, praktif, dan efektif. Jenis Penelitian ini adalah pengembangan atau Research and Development (R\&D ) . Pengembangan R\&D adalah jenis penilitian yang dapat digunakan untuk menghasilkan sebuah produk. Model yang digunakan adalah model ADDIE. ADDIE terdiri dari 5 tahapan yaitu analysis, design, develop, implement dan evaluate. Dari beberapa jurnal yang sudah di telaah penulis mendapatkan hasil bahwa:Media komik berpengaruh terhadap efektifitas belajar peserta didik, membuat peserta didik menjadi termotivasi untuk belajar, dan dapat membuat peserta didik memiliki minat belajar.Hasil validasi yang dilakukan oleh 4 validator diperoleh nilai validitas media rata-rata 79\% dengan kategori valid, nilai validasi RPP rata-rata 94\% dengan kategori sangat valid, nilai validasi soal dengan rata-rata $86 \%$ dengan kategori sangat valid. Selanjutnya nilai praktikalitas memperoleh rata-rata $89 \%$ dengan kategori sangat praktis dan nilai efektivitas memperoleh rata-rata $86 \%$ dengan kategori sangat efektiv. Dari hasil diatas dapat disimpulkan bahwa komik penerapan sila pancasila memenuhi kategori valid dalam arti dapat diterapkan kepada peserta didik, kategori sangat praktis dalam arti mudah digunakan oleh peserta didik, dan kategori sangat efektiv dalam arti komik penerapan sila pancasila dapat membantu peserta didik dalam mencapai tujuan pembelajaran.
\end{abstract}

Kata-kata Kunci: Hasil Belajar, PPKn, Media Komik.

\section{Development of Comic Media for the Implementation of the Precepts of Pancasila for Class 3 Civics in Elementary Schools in Dharmasraya Regency}

\author{
Yulia Darniyanti, Nini Efriani, Wiwik Okta Susilawati
}

\section{Universitas Dharmas Indonesia, Jl Lintas Sumatera Km 18, Koto Baru, Dharmasraya, Sumatera Barat,} Email: efrianinini@gmail.com

\begin{abstract}
This research is motivated by the low learning outcomes of students, in Civics subjects the material diversity of the pancasila precepts. The low learning outcomes of students are caused because students find it difficult to understand the content of Civics and the lack of variety of learning media used in the learning learning process and innovative, creative learning media are needed.The purpose of this learning is to produce comic media for the application of the Pancasila precepts of Civics in Grade 3 Elementary School which is valid, practical, and effective.This type of research is research and development (R\&D).R\&D development is a type of research that can be used to produce a product.The model used is the
\end{abstract}


ADDIE model. ADDIE consists of 5 stages, namely analysis, design, develop, implement and evaluate.From several journals that have been reviewed, the authors get the results that: Comic media affects the effectiveness of student learning, makes students motivated to learn, and can make students have an interest in learning. The results of the validation carried out by 4 validators obtained an average media validity value of $79 \%$ with a valid category, an average $R P P$ validation value of $94 \%$ with a very valid category, an average validation value of $86 \%$ with a very valid category. Furthermore, the practicality value obtained an average of $89 \%$ in the very practical category and the effectiveness value obtained an average of $86 \%$ in the very effective category.From the results above, it can be concluded that the comics of the Pancasila precepts the valid categories in the sense that they can be applied to students, the categories are very practical in the sense that they are easy to use by students, and the categories are very effective in the sense that the diversity the Pancasila precepts comics can help students achieve learning goals.

Keywords: Learning Outcomes, PPKn, Comic Media.

\section{Pendahuluan}

Pendidikan dijadikan acuan dalam menilai maju mundurnya sebuah bangsa. Semakin baik pendidikan sebuah bangsa maka semakin maju bangsa tersebut, karena melalui pendidikan dapat membentuk karakter bangsa. Pendidikan dapat diartikan sebagai usaha sadar dan terencana yang dilakukan manusia untuk membentuk kemampuan, kualitas, dan potensi yang ada di dalam diri seseorang untuk menjalankan segala aspek kehidupan. Hal ini sesuai dengan Undang-Undang Republik Indonesia Nomor 20 Tahun 2003 tentang Sistem Pendidikan Nasional yang berbunyi : "Pendidikan Nasional berfungsi sebagai pengembangan kemampuan dan pembentukan watak serta peradapan bangsa yang bermatabat dalam rangka mencerdaskan kehidupan bangsa, bertujuan untuk berkembangnya potensi peserta didik agar menjadi manusia yang beriman dan bertaqwa terhadap Tuhan Yang Maha Esa, berakhlak mulia, sehat, berilmu, cakap, kreatif, mandiri, dan menjadi warga negara yang demokratis dan bertanggung jawab". Pendidikan di Indonesia banyak mengalami perubahan dikarenakan Indonesia terdampak covid-19. Covid-19 merupakan singkatan dari Coronavirus Disease 2019, jenis penyakit ini disebabkan oleh virus dari golongan Coronavirus yaitu SARS-CoV-2. Covid-19 pertama kali muncul pada tahun 2019 di kota Wuhan Cina yang dapat menular antar sesama manusia dan menyebar dengan sangat cepat. Penyakit ini tidak hanya tejadi disatu kota saja tapi sudah menyebar keseluruh dunia. Covid-19 semakin lama menjadi semakin ganas bahkan dapat menyebabkan kematian (Ainur Risalah, 2020). Goncangan dunia pendidikan yang disebabkan karena adanya covid-19 sangat berdampak terhadap pendidikan di Indonesia, maka sistem pendidika di Indonesia mengalami perubahan yang disesuaikan dengan kondisi yang melanda Indonesia yaitu Covid-19. Sistem pendidikan di Indonesia mengalami perubahan agar dapat menyesuaikan dengan pandemi yang sedang melanda di Indonesia. Segala pihak harus siap dengan kondisi yang sekarang ini, baik itu pemerintah, tenaga kesehatan, TNI, POLRI dan tenaga pendidik (Ainur, 2020). Sistem pendidikan tidak terlepas dari peran pendidik. Pendidik menurut UU No. 20 Tahun 2003, Pasal 39 Ayat 2 merupakan tenaga profesional yang bertugas merencanakan dan melaksanakan proses pembelajaran, menilai hasil pembelajaran, melakukan bimbingan dan pelatihan, serta melakukan penulisan dan pengabdian, terutama untuk pendidikan dan perguruan tinggi. Pendidik yang profesional harus menguasai 4 kompetensi yang harus dikuasai guru. Kompetensi tersebut adalah kompetensi pedagogik, profesional, kepribadian, dan soaial (Wahyu, 2015). Guru yang profesional juga harus menguasai materi, merencanakan 
pembelajaran, memotivasi peserta didik, merancang media dalam proses belajar, dan memilih media yang menarik saat pembelajaran berlangsung (Hamid, 2017). Media pembelajaran adalah alat yang digunakan dalam proses pembelajaran untuk membantu guru dalam proses belajar, untuk menyampaikan pesan yang ingin disampaikan baik berupa kejadian, manusia, dan materi (Marisa, dkk, 2017). Media pembelajaran mempunyai pengaruh yang besar yaitu dapat membantu guru dalam menjelaskan pelajaran, membuat peserta didik memahami materi yang dipelajari, pembelajaran menjadi menarik, dan membuat suasana belajar menjadi asik (Lazuardi, Murti, 2018). Penggunaan media pembelajaran yang sesuai sangat berpengaruh pada proses pembelajaran. Media pembelajaran adalah segala sesuatu yang untuk menyampaikan materi pembelajaran di dalam proses pembelajaran (Prananda, 2020). Pemilihan media pembelajaran perlu memperhatikan beberapa aspek yaitu, karakteristik peserta didik, alokasi waktu, tujuan pembelajaran, dan materi pelajaran yang akan disampaikan (Rodhatul, 2009). Karakteristik peserta didik adalah sifat peserta didik yang beragam atau bermacam-macam. Dalam pemilihan media pembelajaran tentu saja katakteristik peserta didik sangat berpengaruh, karena sebelum memilih media harus mempertimbangkan terlebih dahulu karakeristik peserta didik yang ada. Media pembelajaran yang buat baru atau di daur ulang kembalu dapat meningkatkan minat belajar peserta didik dan dengan begitu dapat melihat bagaimana karakteristik peserta didik tersebut (Desa et al., 2019). Selanjutnya alokasi waktu, dalam pemilihan media pembelajaran tidak boleh memakan waktu terlalu lama (Arsyad, 2014). Media pembelajaran yang menarik dapat meningkatkan minat dan hasil belajar peserta didik (Wulandari et al., 2021). Empat aspek dalam pemilihan media pembelajaran tersebut harus diperhatikan dalam semua pembelajaran yang ada di sekolah dasar. Contohnya pada pelajaran PPKn, harus menggunakan media yang kreatif dan sesuai dengan materi supaya peserta didik lebih mudah memahami materi yang dipelajari. Media yang digunakan dalam proses pembelajaran harus berhubungan dengan materi yang di sampaikan supaya peserta didik memahami materi (Susilawati et al., 2020). PPKn adalah mata pelajaran yang membentuk warga negara untuk memahami dan mampu melaksanakan hak-hak dan kewajiban serta menjadi warna negara yang trampil, cerdas dan berkarakter (Sari, dkk, 2014). Selanjutnya PPKn diartikan sebagai pembelajaran yang mengandung nilai patriotisme, cinta tanah air, semangat bela negara dan menjadikan warga negara yang memiliki budi pekerti (Prasetyo, 2017). Kemudian PPKn juga diartikan sebagai mata pelajaran yang memiliki tiga poin yaitu pembangunan karakter, membentuk peserta didik dan menjadikan warga negara yang baik (Kurniawan, 2013). PPKn merupakan salah satu pelajaran yang wajib di ikuiti oleh peserta didik di sekolah dasar. PPKn dapat memberikan adukasi kepada peserta didik baik dalam proses pembelajaran maupun dalam kehidupan sehari-hari (Efficacy et al., 2020). PPKn dapat menjadikan peserta didik memiliki rasa cinta terhadap tanah air, mencintai produk sendiri, mengetahui tentang hak dan kewajiban serta mengetahui hal-hal yang berhubungan dengan negara (Kurniawan, 2013). Hal itu tentunya sangat berguna bagi generasi muda, oleh karena itu dalam pemilihan media pembelajaran yang akan digunakan perlu memperhatikan materi dan karakteristik peserta didik serta inovatif dan kreatif dan harus memperhatikan karakteristik peserta didik. Hal ini supaya peserta didik menikmati proses belajar dengan senang, pembelajaran menjadi asik, menyengkan dan tujuan pembelajaran dapat tercapai. Berdasarkan observasi pada kegiatan PLP di SDN 03 Tiumang yang dilakukan sejak tanggal 04 Agustus 2020 sampai dengan tanggal 18 Desember 2020, penulis menemukan secara langsung permasalahan pada 
pembelajaran PPKn di SDN 03 Tiumang. Permasalahan pada pembelajaran PPKn tersebut adalah tidak ditemukannya penggunaan media pembelajaran yang kreatif dan inovatif sehingga peserta didik tidak memahami materi yang disampaikan oleh guru. Media pembelajaran yang digunakan hanya terpaku pada buku saja, dan ini menyebabkan peserta didik bosan saat belajar, mengantuk dan tidak tercapainya tujuan pembelajaran Selain permasalahan yang ditemukan saat obsevasi penulis juga melakukan wawancara dengan wali kelas IIIB SDN 03 Tiumang. Wali kelas tersebut mangatakan bahwa pada proses pembelajaran PPKn media yang digunakan hanya terpaku pada buku saja. Tidak ada media baru atau media yang kreatif digunakan saat proses belajar, dalam satu kelas ada 21 peserta didik yang artinya memiliki 21 macam karakteristik yang berbeda. Peserta didik kelas III atau kelas rendah memiliki karakteristik yang berbeda-beda. Karakteristik peserta didik sangat penting untuk diketahui oleh guru, karena guru bisa mempertimbangkan banyak hal setelah mengetahui apa saja karakteristik peserta didik (Septianti \& Afiani, 2020). Guru bisa memilih media apa saja yang bisa dimanfaatkan dalam kegiatan belajar dengan mengetahui karakteristik peserta didik. Karakteristik peserta didik kelas rendah berada pada tahap operasional konkret yaitu anak mulai berpikir secara logis namun masih menggunakan benda yang konrit. Penulis juga melakukan analisis terhadap peserta didik kelas IIIB di SDN 03 Tiumang penulis mendapatkan hasil bahwa peserta didik di kelas IIIB karakteristiknya masih suka belajar sambil bermain, suka dengan benda-benda yang nyata saat proses pembelajaran, suka dengan sesuatau yang memiliki banyak warna dan menyukai buku yang memiliki banyak gambar (Septianti \& Afiani, 2020). Guru harus memperhatikan karteristik peserta didik sebelum memilih media pembelajaran. Karena dengan melihat karakteristik peserta didik guru dapat mempertimbangkan media yang cocok dalam proses belajar. Kegiatan belajar menjagar harus memilih media yang tepat dengan memperhatikan karakteristik peserta didik supaya media yang digunakan bisa membantu semua peserta didik untuk memahami materi yang disampaikan. Dampak dari penggunaan media yang tidak inovatif dan kreatif membuat peserta didik tidak fokus dalam belajar, peserta didik banyak bermain saat guru menjelaskan materi sehingga banyak peserta didik memiliki hasil belajar yang rendah. Berikut ini jumlah peserta didik yang tuntas dan tidak tuntas dalam mata pelajaran PPKn kelas IIIB yang penulis dapatkan dari wali kelas IIIB yang dijelaskan dalam tabel berikut :

Tabel 1. Jumlah ketuntasan nilai PPkn peserta didik kelas III B

\begin{tabular}{llll}
\hline No & Mata Pelajaran & Keterangan & Jumlah \\
\hline 1. & PPKn & Tuntas & 8 orang \\
2. & & Tidak Tuntas & 13 orang \\
\hline
\end{tabular}

Berdasarkan data Tabel 1. dapat dilihat bahwa KKM yang digunakan di SDN 03 Tiumang adalah 75. Peserta didik yang memperoleh nilai diatas KKM adalah sebanyak 8 orang, sedangkan yang memperoleh nilai dibawah KKM adalah sebanyak 13 orang. Jadi dapat disimpulkan bahwa nilai hasil belajar PPKn di SDN 03 Tiumang masih terbilang rendah karena banyak peserta didik yang mendapatkan nilai dibawah KKM ( kriteria ketuntasan minimal ). Penulis melihat secara langsung dari proses pembelajaran kegiatan belajar mengajar dalam penggunaan media pembelajaran sebagain besar memang terjadi seperti yang dipaparkan diatas. Guru disana sudah memahami bagaimana cara mengajar yang baik dan benar, dan juga bagaimana seharusnya penggunaan media dalam kegiatan 
belajar mengajar, namun belum diterapkan secara maksimal. Peserta didik kurang memahami materi dikarenakan guru belum maksimal dalam menggunakan media pembelajaran saat proses belajar. Dari uraian masalah diatas maka dibutuhkan sebuah media pembelajaran yang kreatif dan inovatif untuk dapat meningkatkan hasil belajar peserta didik sehingga tujuan pembelajaran tercapai. Setelah memahami permasalahan yang dialami peserta didik, penulis mengambil solusi yaitu dengan mengambangkan media pembelajaran komik. Komik ini dapat meningkatkan minat belajar peserta didik karena berisi gambar yang tidak membuat peserta didik bosan proses belajar berlangsung (Junioviona, 2020). Media komik ini dapat membantu peserta didik memahami materi yang disampaikan karena dibuat dengan tokoh katun sehingga membuat peserta didik semangat dan tertarik untuk belajar. Media komik ini sesuai dengan karakteristik peserta didik yang masih suka bermain sambil belajar, pada saat membaca kimik peserta didik juga dapat sambil bermain (Rosyida, 2019). Penulis memilih mengembangkan media pembelajaran komik untuk membuat peserta didik memahami materi yang disampaikan guru dan menjadikan pembelajaran lebih menarik dan asik.Berdasarkan masalah yang di paparkan, penulis ingin melakukan penulisan yang berjudul "Pengembangan Media Pembelajaran Komik Penerapan sila pancasila Kelas 3 Di Sekolah Dasar Kabupaten Dharmasraya ". Dari rumusan masalah tersebut tujuan penelitian adalah Menghasilkan media pembelajaran komik penerapan sila pancasila PPKn kelas 3 SD yang valid, praktis dan efektiv.

\section{Metode Penelitian}

Jenis penulisan yang akan digunakan dalam penulisan ini adalah penulisan dan pengembangan atau Research and Development ( R\&D). Research and Develop ( R\&D ) adalah jenis penilitian yang dapat digunakan untuk menghasilkan sebuah produk. Produk yang dihasilkan akan uji untuk melihat kualitas produk yang dihasilkan. Model yang digunakan dalam pengembangan ini adalah model $A D D I E$ yang terdiri dari 5 langkah yaitu analisi, desain, pengembangan, implementasi dan evaluasi (Gafur, 2012). Langkah-langkah model $A D D I E$ adalah sebagai berikut: (1). Analisis. Analisis ini untuk menentukan kebutuhan belajar seperti sumber belajar apa yang akan di kembangkan dan harapan kompetensi apa yang dikuasi peserta didik setelah belajar. Tahap analisisi ini yang dianalisis adalah analisis materi, analisis kebutuhan peserta didik, analisis karakteristik peserta didik dan analisis KD. (2). Desain. Tahap desain ini yaitu merancang pembelajaran atau mengumpulkan bahan-bahan yang diperlukan dalam pengembangan sebuah media pembelajaran. Pada tahap desain ini bahan-bahan yang diperlukan untuk membuat media komik akan dikumpulkan terlebih dahulu . Bahan-bahan yang dikumpulkan seperti gambargambar, materi, serta hal-hal yang dibutuhkan dalam pembuatan komik. (3). Pengembangan. Tahap pengembangan, pada tahap ini menerapkan desain yang telah dibuat sebelumnya. Selanjutnya akan dilakukan validasi oleh ahli desain, ahli materi dan ahli bahasa. Pada tahap pengembangan semua bahan yang telah dikumpulkan pada tahap desain akan dikembangkan menjadi sebuah komik. (4). Implementasi. Implementasi adalah penerapan, jadi produk yang sudah siap akan diberikan kepada peserta didik untuk melihat hasil dari produk yang di kembangkan. Produk yang telah dibuat penulis yaitu, pengembangan media komik keragaman karakteristik PPKn kelas 3. Selanjutnya produk yang sudah siap dibagikan kepada peserta didik saat proses belajar mengajar. (5). Evaluasi. Evaluasi adalah perbaikan, untuk mengetahui efektifitas dan keberhasilan pembelajaran (Suwarto, 2013, 2017). Setelah selesai melakukan implementasi maka akan diketahui apa saja kekurang dari 
produk yang dikembangkan, kelemahan tersebut akan diperbaiki sesuai dengan kritik dan saran dari ahli materi.

\section{Hasil Penelitian}

Berdasarkan deskripsi hasil validasi media komik penerapan sila pancasila oleh validator, deskripsi hasil validitas menunjukkan bahwa, komik penerapan sila pancasila yang sudah dirancang memperoleh nilai $77 \%, 73 \%$, 77\%, dan $88 \%$ dikategorikan valid dengan melakukan perbaikan-perbaikan sesuai dengan masukan dan saran dasri validator. Komik penerapan sila pancasila ini sudah dikategorikan valid, yang artinya sudah bisa diterapkan di sekolah dalam proses pembelajaran. Selanjutnya Praktikalitas merupakan tingkat keterpakaian perangkat pembelajaran. Perangkat pembelajaran dikatakan praktis apabila guru dan peserta didik tidak mengalami kesulitan dalam belajar dan mudah memahaminya. Praktikalitas media komik penerapan sila pancasila diperolah dari hasil analisis penilaian angket respon guru dan angket respon peserta didik. Guru dan peserta didik diminta mengisi angket praktikalitas media komik penerapan sila pancasil berdasarkan petunjuk pengisan angket. Hasil dari analisi angket guru dan angket respon peserta didik menunjukkan bahwa tanggapan guru dan peserta didik terhadap media komik penerapan sila pancasila bisa digunakan dalam pembelajaran olah guru dan peserta didik. Hasil persentase yang diperoleh dari hasil analisi angket respon guru yaitu $91 \%$ dikategorikan sangat praktis, dan hasil analisis angket respon peserta didik yaitu $86 \%$ dikategorikan sangat praktis. Maka diperolah hasil analisis angket respon guru dan hasil analisis angket respon peserta didik dengan rata-rata 89\% dikategorikan sangat praktis. Kemudian Keefektivan pembelajaran biasanya diukur dari hasil belajar peserta didik (Triwahyuni :2017). Hasil lembaf efektivitas media komik penerapan sila pancasila digunakan untuk melihat sejauh mana tingkat keefektifan media komik penerapan sila pancasila yang dikembangkan. Maka diperlukan perancangan yang tepat yang sesuai dengan peserta didik. Hasil belajar peserta didik kelas IIIB SDN 03 Tiumang diketahui peserta didik yang tutas ada sebnayak 18 orang dengan persentase $86 \%$ dikategorikan sangat efektiv dan yang tidak tuntas ada sebanyak 3 dengan persentase $14 \%$ orang. Maka dari persentase efektivitas tersebut media komik penerapan sila pancasila dikategorikan sangat praktis.

\section{Pembahasan}

Berdasarkan deskripsi hasil validasi media komik penerapan sila pancasila oleh validator, deskripsi hasil validitas diatas menunjukkan bahwa, komik penerapan sila pancasila yang sudah dirancang dikategorikan valid dengan melakukan perbaikanperbaikan sesuai dengan masukan dan saran dasri validator. Komik penerapan sila pancasila ini sudah dikategorikan valid, yang artinya sudah bisa diterapkan di sekolah dalam proses pembelajaran. Komik penerapan sila pancasila ini untuk materi semester 2 kelas III sudah valid berdasarkan penilaian validator . materi yang disajikan dalam komik penerapan sila pancasila. Materi didalamnya penerapan sila pancasila, keragaman jenis makanan dan keragaman jenis pakaian. Sebuah media dikatakan valid apabila diukur dari beberapa aspek yaitu aspek bahasa, isi/materi, dan kontruksi (Rodhatul, 2009) (Triwahyuni: 2017). Praktikalitas merupakan tingkat keterpakaian perangkat pembelajaran. Perangkat pembelajaran dikatakan praktis apabila guru dan peserta didik tidak mengalami kesulitan dalam belajar dan mudah memahaminya. Praktikalitas media komik penerapan sila 
pancasila diperolah dari hasil analisis penilaian angket respon guru dan angket respon peserta didik. Guru dan peserta didik diminta mengisi angket praktikalitas media komik penerapan sila pancasil berdasarkan petunjuk pengisan angket. Hasil dari analisi angket guru dan angket respon peserta didik menunjukkan bahwa tanggapan guru dan peserta didik terhadap media komik penerapan sila pancasila bisa digunakan dalam pembelajaran olah guru dan peserta didik. Hasil persentase yang diperoleh dari hasil analisi angket respon guru yaitu 91\% dikategorikan sangat praktis, dan hasil analisis angket respon peserta didik yaitu $86 \%$ dikategorikan sangat praktis. Maka diperolah hasil analisis angket respon guru dan hasil analisis angket respon peserta didik dengan rata-rata $89 \%$ dikategorikan sangat praktis. Keefektivan pembelajaran biasanya diukur dari hasil belajar peserta didik (Triwahyuni :2017). Hasil lembaf efektivitas media komik penerapan sila pancasila digunakan untuk melihat sejauh mana tingkat keefektifan media komik penerapan sila pancasila yang dikembangkan. Maka diperlukan perancangan yang tepat yang sesuai dengan peserta didik. Hasil belajar peserta didik kelas IIIB SDN 03 Tiumang diketahui peserta didik yang tutas ada sebnayak 18 orang dengan persentase $86 \%$ dikategorikan sangat efektiv dan yang tidak tuntas ada sebanyak 3 dengan persentase $14 \%$ orang. Maka dari persentase efektivitas tersebut media komik penerapan sila pancasila dikategorikan sangat praktis.

\section{Simpulan dan Saran}

Berdasarkan pengembangan yang telah dilakukan terhadap komik pembelajaran PPKn, mata pelajaran PPKn di kelas III B SDN 03 Tiumang dapat disimpulkan Pengembangan media komik penerapan sila pancasila PPKn kelas III menggunakan model ADDIE yang dapat diuji cobakan di kelas III SDN 03 Tiumang.Validasi media komik penerapan sila pancasila PPKn kelas III yang dinilai oleh validator yang berjumlah 4 orang, yaitu 3 orang dosen UNDHARI dan 1 orang guru sekolah dasar. Validasi menunjukkan bahwa komik penerapan sila pancasila di sekolah memperoleh persentase $79 \%$ dengan kategori valid.Pratikalitas yang dinilai dari angket respon guru dan angket respon peserta didik terhadap komik penerapan sila pancasila di sekolah, oleh guru kelas III B dan peserta didik kelas III B SDN 03 Tiumang memperoleh persentase 89\% dekategorikan sangat praktis.Efektifitas dinilai dari hasil belajar peserta didik. Hasil belajar peserta didik memperoleh persentase $86 \%$ dikategorikan sangat efektif. Serta saran diharapkan guru dapat menggunakan media komik penerpan sila pancasila dalam proses pembelajaran agar peserta didik lebih mudah memahami materi yang disampaikan. Untuk pengembangan media pembelajaran selanjutnya, semoga media pembelajaran komik penerapan sila pancasila di sekolah ini, bisa dikembangkan lebih sempurna lagi dengan menggunakan metode yang baru.

\section{Daftar Rujukan}

Ainur Risalah, W Ibad, L Maghfiroh, M I Azza, S A Cahyani, \& Z A Ulfayati. (2020). Dampak Pandemi Covid-19 Terhadap Kegiatan Belajar Mengajar Di MI/SD (Studi KBM Berbasis Daring Bagi Guru dan Siswa). JIEES : Journal of Islamic Education at Elementary School, 1(1), 10-16. https://doi.org/10.47400/jiees.v1i1.5

Arsyad, A. (2014). Media Pembelajaran. PT RajaGrafindo Persada.

Bagja, W. (2015). kompetensi Pedagogik Guru. 1(1), 75-86.

Desa, D. I., Rumbai, P., \& Seberida, K. (2019). Values: Jurnal Pengabdian Kepada 
Masyarakat Values: Jurnal Pengabdian Kepada Masyarakat. 1(01), 42-49.

Efficacy, S., Dalam, S., Tematik, P., Iv, K., Percobaan, S. D. N., \& Padang, K. (2020). ijtveT. 1(1), 31-36.

Gafur, A. (2012). Desain Pembelajaran Konsep,Model,dan Aplikasinya dalam Perencanaan Pembelajaran (W. Djaja (ed.)). Ombak.

Hamid, A. (2017). Guru Profesional. XVII, 274-285.

Junioviona, A. Q., Setyowati, N., \& Yani, M. T. (2020). Pengembangan Komik sebagai Media Pembelajaran untuk Meningkatkan Hasil Belajar Siswa Materi Sikap yang Mencerminkan Sila-sila Pancasila Kelas III Sekolah Dasar. Jurnal Education and Development Institut, 8(3), 95-100.

Kurniawan, M. I. (2013). Pembelajaran Kewarganegaraan.

Lazuardi, D. R., \& Murti, S. (2018). Peningkatan Kemampuan Menulis Puisi Menggunakan Model Pembelajaran Quantum Tipe VAK (Visual, Audiovisual, Kinestetik). Jurnal Kajian Bahasa, Sastra Dan Pengajaran (KIBASP), 2(1), 87-95. https://doi.org/10.31539/kibasp.v2i1.408

Marisa, D. (2017). Komputer dan Media Pembelajaran (E. Purwanto (ed.); 1st ed.). Universitas Terbuka.

Prananda, G. (2020). Pengembngan Media Video Pembelajaran Tema 6 Subtema 2 Untuk Siswa Kelas SD Negeri 17 Pasar Masurai 1. Jurnal Dharma PGSD, 1(1), 38-45. http://ejournal.undhari.ac.id/index.php/judha\%0APengembngan

Prasetyo, A., \& Wahono, M. (2017). Pendidikan Kewarganegaraan: usaha konkret untuk memperkuat multikulturalisme di Indonesia. 14.

Rodhatul, J. (2009). Media Pembelajaran. In Media Pembelajaran.

Rosyida. (2019). Pengembangan Media Komik untuk Meningkatkan Hasil Belajar Siswa Sekolah Dasar Ais Rosyida Institut Agama Islam Sunan Giri (INSURI) Ponorogo. 11(1), 47-63.

Sari, T. I., Mardiati, Y., \& Khutobah. (2014). Penerapan Metode Diskusi dengan Menggunakan Media Gambar Untuk Meningkatkan Aktivitas dan Hasil Belajar Siswa kelas III dalam Pembelajaran Pkn Tema Lingkungan di SDN Sumberlesung 02 Ledokombo Jember ( The Application of Learning Discussion Method by Using. Edukasi Unej, I(2), 36-39.

Septianti, N., \& Afiani, R. (2020). Pentingnya Memahami Karakteristik Siswa Sekolah Dasar di SDN Cikokol 2. As-Sabiqun, 2(1), 7-17. https://doi.org/10.36088/assabiqun.v2i1.611

Susilawati, W. O., Darniyanti, Y., Prasetyo, D. E., Apreasta, L., \& Novitasari, A. (2020). Urgency of Adiwiyata School for education as sustainable development. Journal of Education and Learning (EduLearn), 14(4), 543-549. https://doi.org/10.11591/edulearn.v14i4.15584

Suwarto, D. (2013). Pengembangan Tes Diagnostik Dalam Pembelajaran. Yogyakarta: Pustaka Pelajar.

Suwarto, S. (2017). Pengembangan tes ilmu pengetahuan alam terkomputerisasi. Jurnal Penelitian dan Evaluasi Pendidikan, 21(2), 153-161.

Wulandari, R. A., Wiska, M., Susilawati, W. O., Efendi, R., \& Darniyanti, Y. (2021). Juridical Analysis of Transitional Land Rights Unregistered in Dharmasraya Regency. Proceedings of the 1st Paris Van Java International Seminar on Health, Economics, Social Science and Humanities (PVJ-ISHESSH 2020), 535, 566-570. 